\title{
Production of butanol and hydrogen by fermentation techniques using steam treated municipal solid waste
}

EU BESTF2 MSWBH

Authors: Truus de Vrije, Pieternel A.M. Claassen

Institute: WFBR

This research project has been carried out by Wageningen Food \& Biobased Research commissioned by the Dutch Ministry of Economic Affairs and funded by RVO, in the context of ERANET Plus BESTF2 (project number BESTF14001).

Wageningen Food \& Biobased Research

Wageningen, October 2018

Public

Report number 1871

ISBN: 978-94-6343-373-0 
Version: final

Client: the Dutch Ministry of Economic Affairs

Sponsor: RVO

This report can be downloaded for free at http://doi.org/10.18174/463764 or at www.wur.eu/wfbr (under publications).

(C) 2018 Wageningen Food \& Biobased Research, institute within the legal entity Stichting Wageningen Research.

The client is entitled to disclose this report in full and make it available to third parties for review. Without prior written consent from Wageningen Food \& Biobased Research, it is not permitted to:

a. partially publish this report created by Wageningen Food \& Biobased Research or partially disclose it in any other way;

b. (let a third party) use this report created by Wageningen Food \& Biobased Research or the name of the report or Wageningen Food \& Biobased Research in whole or in part for the purposes of making claims, conducting legal procedures, for (negative) publicity, and for recruitment in a more general sense;

c. use the name of Wageningen Food \& Biobased Research in a different sense than as the author of this report.

PO box 17, 6700 AA Wageningen, The Netherlands, T + 31 (0)317 4800 84, E info.wfbr@wur.nl, www.wur.eu/wfbr. Wageningen Food \& Biobased Research is part of Wageningen University \& Research.

All rights reserved. No part of this publication may be reproduced, stored in a retrieval system of any nature, or transmitted, in any form or by any means, electronic, mechanical, photocopying, recording or otherwise, without the prior permission of the publisher. The publisher does not accept any liability for inaccuracies in this report. 


\section{Contents}

1 Gegevens project $\quad 4$

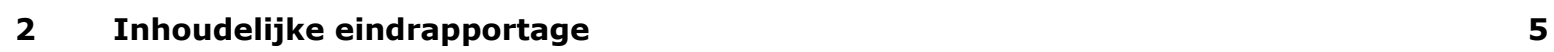

$\begin{array}{lll}2.1 & \text { Summary } & 5\end{array}$

$\begin{array}{ll}2.2 \text { Introduction } & 5\end{array}$

$\begin{array}{lll}2.3 \text { Aim } & 6\end{array}$

2.4 Materials and Methods $\quad 6$

2.4.1 Waste composition, pretreatment and hydrolysis $\quad 6$

2.4.2 Microorganism and cultivation $\quad 6$

$\begin{array}{lll}2.5 & \text { Results } & 7\end{array}$

$\begin{array}{lll}2.5 .1 & \text { Small scale batch fermentations } & 7\end{array}$

$\begin{array}{lll}2.6 & \text { Discussion } & 9\end{array}$

$\begin{array}{lll}2.7 & \text { Conclusion and recommendations } & 9\end{array}$

$\begin{array}{llr}3 & \text { Uitvoering van het project } & 10\end{array}$

$\begin{array}{llr}3.1 & \text { Problemen tijdens project en oplossingen } & 10\end{array}$

3.2 Wijzigingen t.o.v. het projectplan $\quad 10$

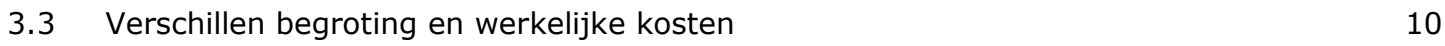

$\begin{array}{lll}3.4 & \text { Wijze van kennisverspreiding } & 10\end{array}$

$\begin{array}{llr}3.5 & \text { PR project en verdere PR mogelijkheden } & 10\end{array}$ 


\section{$1 \quad$ Gegevens project}

Projectnummer

Projecttitel

Penvoerder (geen medeaanvragers)

Projectperiode
BESTF14001

Production of butanol and hydrogen by fermentation techniques using steam treated municipal solid waste (MSWBH)

P.A.M. Claassen

01-04-2016-01-09-2018 


\section{Inhoudelijke eindrapportage}

\subsection{Summary}

The project MSWBH "Production of butanol and hydrogen by fermentation techniques using steam treated municipal solid waste" was partially funded by RVO (Rijksdienst voor Ondernemend Nederland) in the context of ERANET Plus BESTF2. Wageningen Food \& Biobased Research was partner in this project with HyGear as sub-contractor. Other MSWBH partners were located in the UK and Norway and funded by Innovate UK in the context of the same programme. These partners were:

- Wilson Bio-Chemical Ltd (Coordinator; sponsor WFBR)

- University of York and the Biorenewables Development Centre

- University of Nottingham

- Artech Automation AS, Norway

The project duration was from April 1, 2016 till August 31, 2019.

The application of high pressure and steam is a proven method for the mobilisation of valuable components from biomass. It is used in the project "Production of butanol and hydrogen by fermentation techniques using steam treated municipal solid waste (MSWBH)" for the conversion of municipal solid waste (MSW) in the United Kingdom into suitable feedstock for the pilot-scale production of butanol and hydrogen, which are important fuels and chemicals.

Butanol, acetone and ethanol were produced from the sugar fraction of hydrolysed steam-treated MSW biofibre by Clostridium acetobutylicum. High ABE yields approaching the maximum theoretical value were obtained with a biofibre fraction that was washed prior to hydrolysis for removal of inhibiting components.

The first part of the project was successfully completed, i.e. the target ABE yield on biofibre hydrolysate sugars was achieved at laboratory scale. The next part of the project, fermentations at pilot scale and butanol and hydrogen gas recovery from the broth by gas stripping, and the technology transfer of the process for fermentation at demo scale (to be performed in York, UK) was not carried out.

\subsection{Introduction}

The application of high pressure and steam is a proven method for the mobilisation of valuable components from biomass. It is used in the project "Production of butanol and hydrogen by fermentation techniques using steam treated municipal solid waste (MSWBH)" for the conversion of municipal solid waste (MSW) in the United Kingdom into suitable feedstock for the pilot-scale production of butanol and hydrogen, which are important fuels and chemicals. The project contributes to the EU's commitment to ensure that 10 percent of all transport fuels are biobased by 2020 .

In the UK there is no source separation of municipal solid waste. Municipal waste is separated after collection, first by removal of plastics, metals and other non-organic components. The remaining organic solid waste is treated with high pressure and steam to produce a carbohydrate-rich stream (the biofibre fraction). This stream is converted into butanol and hydrogen by anaerobic bacteria during a fermentation process.

The treatment of the municipal solid waste is done in the UK by the technology developed by Wilson Bio-Chemicals in an autoclave-type equipment, that is installed at the Biorenewables Development Centre (BDC) in York. After the steam treatment, the waste is sanitised and easier to degrade. The carbohydrates in the pre-treated material are hydrolysed by enzymes (University of Nottingham), and the resulting sugar stream is fermented by anaerobic bacteria that can use many different sugars to produce butanol and hydrogen (WFBR). The data obtained during the research and the pilot phases 
provide a basis for evaluation of the technical and economic feasibility of the new process (University of Nottingham).

In MSWBH, Wageningen Food \& Biobased Research studies and optimises the use of the sugars by selected bacteria and also determines the effect of other components on the growth of these bacteria. MSW may contain many different components coming from all kinds of sources, including plants, food waste and paper. This can affect the fermentation performance. The complete process from MSW to pure butanol and hydrogen will be realised in Wageningen. At the end of the project, the technology will be scaled up in a pilot facility at BDC.

\subsection{Aim}

The aim of MSWBH is to develop a process and build a pilot plant for the production of butanol and hydrogen from municipal solid waste by using established MSW autoclaving treatment technology as a pretreatment of biomass.

\subsection{Materials and Methods}

\subsubsection{Waste composition, pretreatment and hydrolysis}

The waste used in this project is representative of municipal solid waste in the UK with the following wet composition by mass: paper and cardboard (22\%), food waste $(17 \%)$, wood $(8.7 \%)$, plastic $(22 \%)$, glass $(1 \%)$, garden waste $(3 \%)$, metals $(4 \%)$, textiles $(6.6 \%)$ and others $(15.7 \%)$

(Department for Environmental Food and Rural Affairs (Defra), 2017).

A cellulose-rich biofibre fraction was recovered from steam treated MSW using high pressure saturated steam in an autoclave system as developed by Wilson Bio-Chemical (Wilson Bio-Chemical, 2017). Optimized steam treatment condition for MSW in a batch process was at $160{ }^{\circ} \mathrm{C}$ for $60-90 \mathrm{~min}$. The biofibre fraction was enzymatically hydrolysed to fermentable, soluble sugars using cellulase activity (Cellic Ctec2, Novozymes). Enzymatic hydrolysis was at a biofibre concentration of 20\% (dry matter of biofibre per volume), varying enzyme loading (Table 1), initial pH 5.0, temperature $50{ }^{\circ} \mathrm{C}$, duration $48 \mathrm{~h}$. pH control was done by buffering the slurry with citric acid or by initial adjustment with sulphuric acid. Addition of sulphuric acid for $\mathrm{pH}$ maintenance was continued during incubation. The hydrolysate was clarified by centrifugation.

WFBR received the hydrolysates tested in this project from the University of Nottingham (UK), Dr. Roger Ibbett. The hydrolysates were prepared by the University of Nottingham from biofibre fractions received from Wilson Bio-Chemical, Mr. Pete Metcalf.

\subsubsection{Microorganism and cultivation}

Clostridium acetobutylicum ATCC 824 was cultivated in CM2 medium which contained (per L) $\mathrm{KH}_{2} \mathrm{PO}_{4} 1$ $\mathrm{g}, \mathrm{K}_{2} \mathrm{HPO}_{4} 0.76 \mathrm{~g}, \mathrm{CH}_{3} \mathrm{COONH}_{4} 2.9 \mathrm{~g}$ (of which acetate is $2.2 \mathrm{~g}$ ), yeast extract $2.5 \mathrm{~g}, \mathrm{FeSO}_{4} .7 \mathrm{H}_{2} \mathrm{O} 6.6$ $\mathrm{mg}, \mathrm{MgSO}_{4} .7 \mathrm{H}_{2} \mathrm{O} 1 \mathrm{~g}$, and $p$-aminobenzoic acid $(p-\mathrm{ABA}) 0.1 \mathrm{~g}$. The sugar content of the hydrolysates and the volumes of hydrolysate in the culture medium $(\mathrm{v} / \mathrm{v})$ are shown in Table $1 . \mathrm{pH}$ was adjusted to 6.5. Antifoam 204 (Sigma) was added to prevent foaming during fermentation. The culture medium was made anaerobic by $\mathrm{N}_{2}$ sparging and was pasteurised $\left(80^{\circ} \mathrm{C}, 30 \mathrm{~min}\right.$ ) prior to inoculation. Small scale batch fermentations were carried out in $118 \mathrm{~mL}$ anaerobic serum flasks with $50 \mathrm{~mL}$ of culture medium with pure sugars (control) or the, nearly, equivalent amount of sugars in hydrolysate as the substrates. 
Table $1 \quad$ Overview of biofibre hydrolysates and wash water for ABE fermentation.

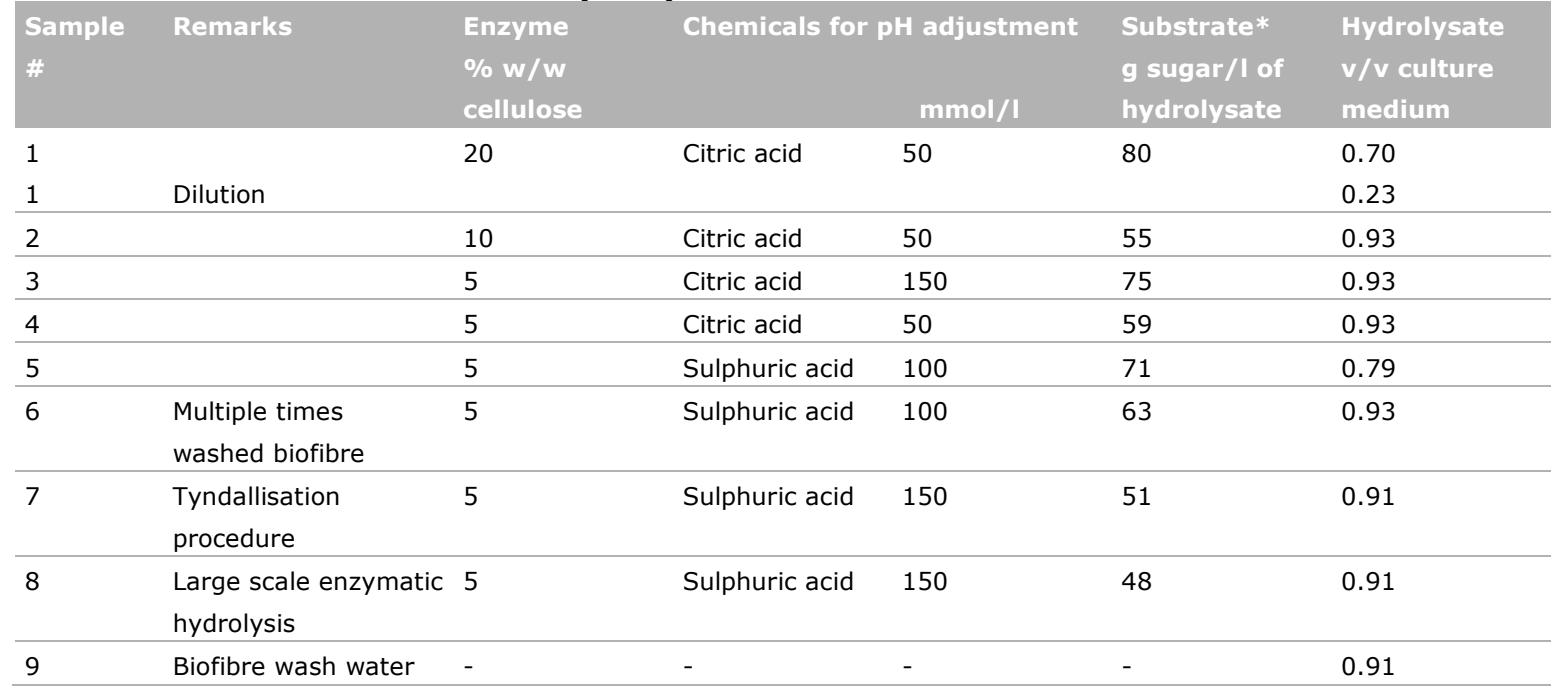

*Substrate in hydrolysates was a mixture of glucose and xylose.

\section{$2.5 \quad$ Results}

\subsubsection{Small scale batch fermentations}

Fermentability of MSW biofibre hydrolysates by C. acetobutylicum ATCC 824 was tested in small scale batch fermentations. Nine batches of hydrolysates were prepared (by the University of Nottingham) with variation in enzyme loading, chemicals for $\mathrm{pH}$ adjustment and prior treatment of the biofibre fraction, i.e. multiple times washing with water for removal of inhibitors or 3 times autoclaving with intermittent incubation at $30^{\circ} \mathrm{C}$ (Tyndallisation method) to kill heat-resistant spores.

A high ABE titre of $14.6 \mathrm{~g} / \mathrm{l}$ and sugar consumption by $C$. acetobutylicum were achieved on medium with hydrolysate prepared from washed biofibre (sample \#6) (Fig. 1). This was comparable to control fermentations with the corresponding pure sugars. In all other cultivations with biofibre hydrolysate fermentation was inhibited except for sample \#2. Dilution of the hydrolysate in culture medium prevented inhibition of fermentation (sample \#1). Application of an extensive sterilisation protocol for the biofibre fraction (sample \#7) was without effect indicating that fermentation was not affected by endogenous contaminants. Possible inhibitors are soluble components present in the biofibre fraction which ended up in the wash water (sample \#9). 
Table 2 Results of ABE fermentations by C. acetobutylicum ATCC 824 on medium with biofibre hydrolysate (samples \# 1-9) or with pure sugars (Control).

\begin{tabular}{|c|c|c|c|c|}
\hline \multirow{2}{*}{$\begin{array}{l}\text { Sample } \\
\#\end{array}$} & \multicolumn{2}{|c|}{ Substrate consumption } & \multirow{2}{*}{$\begin{array}{l}\text { ABE production } \\
\text { g/I }\end{array}$} & \multirow{2}{*}{$\begin{array}{l}\text { ABE yield } \\
\text { g ABE/g sugar }\end{array}$} \\
\hline & $\mathrm{g} / 1$ & $\%$ & & \\
\hline Control & 52 & 85 & 15.7 & 0.30 \\
\hline Control + Antifoam & 50 & 82 & 14.6 & 0.29 \\
\hline 1 & 25 & 43 & 4.9 & 0.20 \\
\hline 2 & 44 & 85 & 14.6 & 0.33 \\
\hline 3 & 16 & 22 & 1.4 & 0.09 \\
\hline 4 & 20 & 36 & 1.3 & 0.06 \\
\hline 5 & 20 & 35 & 3.0 & 0.14 \\
\hline wash water & $19 * *$ & 33 & 1.3 & 0.07 \\
\hline
\end{tabular}

Culture medium with diluted hydrolysate* or wash water** was supplemented with pure glucose ( $33 \mathrm{~g} / \mathrm{l})$ and a glucose-xylose mixture, resp.

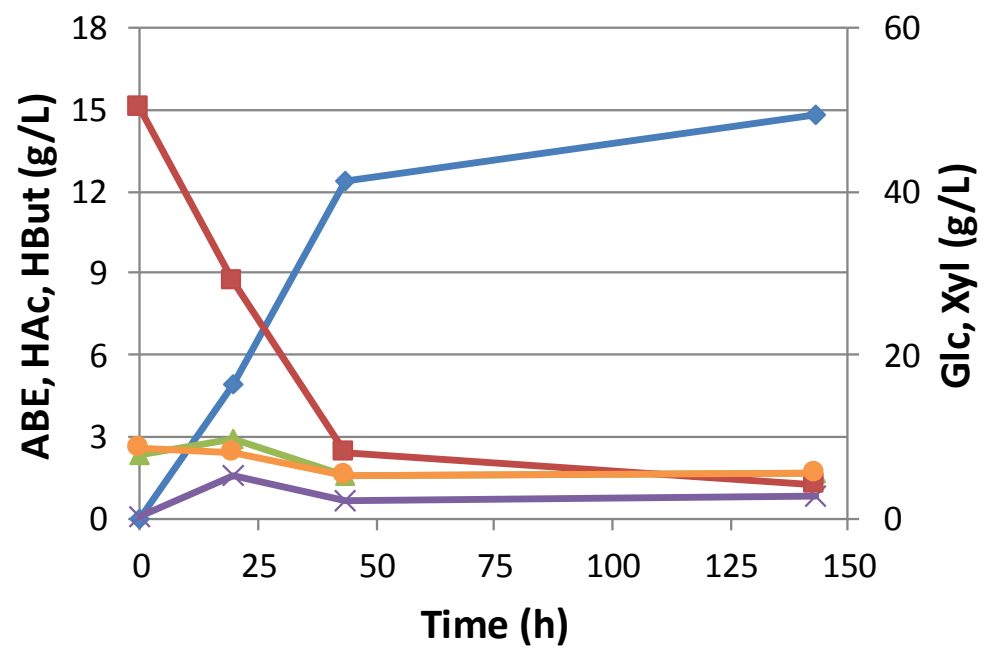

$\leadsto \mathrm{ABE} \rightarrow \mathrm{HAc} \leftarrow \mathrm{HBut} \leftarrow \mathrm{Glc} \rightarrow \mathrm{Xyl}$

Figure 1 ABE production by C. acetobutylicum ATCC 824 from hydrolysed MSW biofibre (sample \#6). (ABE: butanol $9.2 \mathrm{~g} / \mathrm{l}$, acetone $4.1 \mathrm{~g} / \mathrm{l}$, ethanol $1.5 \mathrm{~g} / \mathrm{l}$ ). HAc, acetic acid; HBut, butyric acid; Glc, glucose; Xyl, xylose. 


\subsection{Discussion}

We have shown that butanol, acetone and ethanol can be produced from the sugar fraction of hydrolysed steam-treated MSW biofibre by Clostridium acetobutylicum. High ABE yields were obtained after prior removal of water-soluble inhibitors from the biofibre fraction by washing with water. This needs to be confirmed by further experiments. The nature of the inhibitors is presently unknown. Microbial contamination in the biofibre fraction did not play a role in inhibition of fermentation. More than $90 \%$ of glucose, the main sugar in the fermentable biofibre hydrolysate was consumed and converted with a high yield to butanol, acetone and ethanol.

\subsection{Conclusion and recommendations}

The first part of the project was successfully completed, i.e. the target ABE yield on biofibre hydrolysate sugars was achieved at laboratory scale and a method to minimize the effects of inhibitors present in the biofibre fraction was developed.

The next part of the project, fermentations at pilot scale and butanol and hydrogen gas recovery from the broth by gas stripping, and the technology transfer of the process for fermentation to demo scale (to be performed in York, UK) was not carried out.

\section{References}

Department for Environmental Food and Rural Affairs (Defra). 2017. Digest of Waste and Resource Statistics - 2017 Edition

Wilson Bio-Chemical. 2017. http://wilsonbio-chemical.co.uk/ 


\title{
$3 \quad$ Uitvoering van het project
}

\subsection{Problemen tijdens project en oplossingen}

Het project is vroegtijdig en uiteindelijk definitief stopgezet (najaar 2017) vanwege het niet nakomen van de betalingsverplichtingen van Wilson Bio-Chemical aan WFBR. Daardoor is het niet mogelijk gebleken om de mijlpalen en doelstellingen te realiseren.

\subsection{Wijzigingen t.o.v. het projectplan}

De eerste fase van het project is volgens het projectplan verlopen. De fases daarna zijn niet tot uitvoering gekomen.

\subsection{Verschillen begroting en werkelijke kosten}

De begroting vermeldt totale kosten van $€ 250.000$. De gerealiseerde kosten bedragen $€ 81.615,75$. De beperkte uitputting van het budget is ontstaan door het vroegtijdig stopzetten van het project zoals genoemd onder 3.1.

\subsection{Wijze van kennisverspreiding}

Manuscript, submitted:

"Process design and life cycle assessment of butanol and hydrogen production from autoclaved municipal solid waste", by Fanran Meng, Roger Ibbett, Truus de Vrije, Pete Metcalf, Gregory Tucker, Jon McKechnie.

\subsection{PR project en verdere PR mogelijkheden}

\author{
Van huishoudelijk afval naar butanol en waterstof - WUR \\ https://www.wur.nl/nl/project/Van-huishoudelijk-afval-naar-butanol-en-waterstof.htm MSWBH \\ gebruikt huishoudelijk afval in het Verenigd Koninkrijk voor de productie van grondstof voor \\ fermentatie naar butanol en waterstof, beide belangrijke ... \\ Van huishoudelijk afval naar butanol en waterstof: Duurzaam nieuws \\ https://www.duurzaamnieuws.nl/van-huishoudelijk-afval-naar-butanol-en-waterstof/ 4 jan. 2018 - In \\ het MSWBH project wordt huishoudelijk afval in het Verenigd Koninkrijk gebruikt voor de productie \\ van grondstof voor fermentatie naar ... \\ Conversion of Municipal Waste into Butanol and Hydrogen | KIVI \\ https://www.kivi.nl/.../conversion-of-municipal-waste-into-butanol... \\ Wageningen/The Netherlands - MSWBH uses municipal waste in the United Kingdom to produce \\ feedstock for fermentation into butanol and hydrogen, which ... \\ butanol Archieven - Petrochem \\ https://www.petrochem.nl/tag/butanol/'Production of butanol and hydrogen by fermentation \\ techniques using steam treated municipal solid waste (MSWBH)' getest op pilotschaal. In het project \\ wordt ... \\ Biobrandstof en chemicaliën uit groenafval - Agro\&Chemie ... \\ https://www.agro-chemie.nl/nieuws/biobrandstof-en-chemicalien-groenafval/ 28 dec. 2017 - Bij het \\ Biorenewables Development Centre (BDC) in York (VK) worden met stoom en hogedruk \\ koolhydraatrijke grondstoffen uit het ...
}


bestf 2 mswbh - GtR

https://gtr.ukri.org/projects?ref=620103 The Gateway to Research: UKRI portal onto publically funded research.[PDF] MSWBH - Municipal Solid Waste to Butanol and Hydrogen. 12. BIOWAMET - BIO-

Methane Production from Urban Organic Matter. 13. The Added Value of ...

de Duurzame Wereld: 01/04/18 https://www.deduurzamewereld.eu/2018_01_04_archive.html 4 jan. 2018 - ... getiteld "Production of butanol and hydrogen by fermentation techniques using steam treated municipal solid waste (MSWBH)", ingezet ...

Van huishoudelijk afval naar butanol en waterstof | Jobs in Energy ...

https://jobsinenergy.nl/2018/01/.../van-huishoudelijk-afval-naar-butanol-en-waterstof/ 4 jan. 2018 ... solid waste (MSWBH)", ingezet voor de conversie van huishoudelijk afval (MSW) naar een geschikte grondstof voor de productie van butanol ...

Project Coordinator Acronym Value chain Participant Countries ... - bestf eranetbestf.net/wp-content/uploads/2012/.../BESTF2-Projects.pdf WILSON. STEAM. STORAGE. MSWBH. 6. United. Kingdom,. Spain,. The. Netherlands. Overall aim: Cost competitive production of biobutanol and hydrogen via.

Produce important fuels and chemicals from municipal waste ...

chemindigest.com > othernews The project is abbreviated as MSWBH, where MSW stands for municipal solid waste and $\mathrm{B}$ and $\mathrm{H}$ stands for butanol and hydrogen respectively. Wageningen ...

Efficient Splitting of Water for Hydrogen Production

https://www.lab-worldwide.com/efficient-splitting-of-water-for-hy...

25 jan. 2018 - ... of butanol and hydrogen by fermentation techniques using steam treated municipal solid waste (MSWBH)" with its expertise on fermentation ...

Bioenergy - from Research to Market Deployment in a European ...

www.etipbioenergy.eu/.../198-bioenergy-from-research-to-market...

09:30 MSWBH - Production of butanol and hydrogen by fermentation techniques using steam treated municipal solid waste (MSW) Jo ROSS, Biorenewables ... 